\title{
EDITORIAL 2017: REFLECTIONS AND CURRENT INSIGHTS
}

\author{
Daniel Matulić ${ }^{*}$, Tea Tomljanović \\ University of Zagreb, Faculty of Agriculture, 10000 Zagreb, Croatia \\ *Corresponding Author, Email: dmatulic@agr.hr
}

\section{ARTICLE INFO}

Available online: 1 March 2017

\begin{abstract}
The Croatian Journal of Fisheries (Croat J Fish) continues in its effort to maintain an important role among scientific and professional journals in fisheries. In the aim of increasing the visibility of academic publications, De Gruyter Open has teamed up with Kudos. Croat J Fish has been accepted into BIOSIS Citation Index under Clarivate Analytics - Web of Science. CiteScore metrics from Scopus are presented below. The Editorial also provides information on the articles published in 2016, as well as a list of reviewers who participated in the review process.
\end{abstract}

\section{STATE OF THE JOURNAL}

Croat J Fish is a successful scientific and technical journal with a long publishing tradition that helped safekeeping and improving the knowledge of the fisheries in Croatia and other world countries. The first issue of Croat J Fish was released in 1938 and, this year, the Journal is celebrating 79 years of publishing. Political and administrative circumstances have changed many times during that period - Croat J Fish has existed through two wars and five changes in statehood. One of the main goals of publishing Croat J Fish has remained unchanged - to publish scientific and professional papers on many disciplines that improve our understanding of the fisheries sciences. Additionally, Clarivate Analytics (e.g. Thomson Reuters) still evaluates Croat J Fish for SCI database.

\section{KUDOS AND BIOSIS CITATION INDEX}

De Gruyter Open, a leading publisher of Open Access academic content which publishes Croat J Fish, has teamed up with Kudos https://www.growkudos.com/ - a webbased service that aims to increase the visibility of academic publications and their eventual impact. The service provides a clear picture to researchers, publishers and institutions of how to optimise their communication activity. Recent investigations have suggested that when researchers explain and share their work, downloads of the full text increase by 23\% (Rapple, 2016).

In 2016, Croat J Fish was accepted into BIOSIS Citation Index on Clarivate Analytics -Web of Science. BIOSIS Citation Index is the world's most comprehensive reference database for life sciences research which provides a comprehensive view of life sciences research, including the most important discoveries, significant influences and relevant connections. Biosis Citation Index ${ }^{S M}$ combines critical life sciences research with powerful citation indexing that only Web of Science ${ }^{\mathrm{TM}}$ provides. Web of Science is today's premier research platform for information in the sciences - social sciences, arts and humanities, and with BIOSIS Citation Index subscription Croat J Fish is a step closer to getting its impact factor. With the help and cooperation from the authors and 
Table 1. Topics covered by the Croatian Journal of Fisheries and titles of published papers in 2016 (Original scientific paper - OS; Preliminary communication - PC; Review article - RA; Short communication - SC, Professional paper - PP)

\begin{tabular}{|c|c|c|c|c|}
\hline $\begin{array}{l}\text { MAIN } \\
\text { SUBJECT } \\
\text { CATEGORY }\end{array}$ & PAPER TITLE & $\begin{array}{l}\text { PEER } \\
\text { REVIEW }\end{array}$ & REFERENCES & $\begin{array}{l}\text { Type } \\
\text { of } \\
\text { article }\end{array}$ \\
\hline \multirow{6}{*}{$\begin{array}{l}\text { Freshwater } \\
\text { Aquaculture }\end{array}$} & The effect of water renewal on growth of Clarias gariepinus fingerlings & Yes & $\begin{array}{l}\text { Okomoda et al., } \\
2016\end{array}$ & SC \\
\hline & $\begin{array}{l}\text { Effects of storage conditions on quality characteristics of commercial aquafeeds and } \\
\text { growth of African catfish Clarias gariepinus }\end{array}$ & Yes & $\begin{array}{l}\text { Solomon et al., } \\
2016\end{array}$ & PP \\
\hline & $\begin{array}{l}\text { Dynamics of the adoption of improved aquaculture technologies among fish farmers in } \\
\text { Lagos State, Nigeria }\end{array}$ & Yes & $\begin{array}{l}\text { Olaoye et al., } \\
2016\end{array}$ & OS \\
\hline & $\begin{array}{l}\text { A review of introduction of common carp Cyprinus carpio in Pakistan: origin, purpose, } \\
\text { impact and management }\end{array}$ & Yes & $\begin{array}{l}\text { Khan et al., } \\
2016\end{array}$ & RA \\
\hline & $\begin{array}{l}\text { Cannibalism and performance evaluation of hybrids between Clarias batrachus and } \\
\text { Clarias gariepinus }\end{array}$ & Yes & $\begin{array}{l}\text { Olufeagba and } \\
\text { Okomoda, } 2016\end{array}$ & SC \\
\hline & $\begin{array}{l}\text { The protective role of vitamin } \mathrm{C} \text { and chitosan against paraquat-induced oxidative stress } \\
\text { in muscles of common carp (Cyprinus carpio) }\end{array}$ & Yes & $\begin{array}{l}\text { Sharifinasab et } \\
\text { al., } 2016\end{array}$ & OS \\
\hline $\begin{array}{l}\text { Marine } \\
\text { Aquaculture }\end{array}$ & Meagre (Argyrosomus regius Asso, 1801) aquaculture in Croatia & Yes & $\begin{array}{l}\text { Kružić et al., } \\
2016\end{array}$ & RA \\
\hline \multirow{2}{*}{ Fish disease } & $\begin{array}{l}\text { Occurrence and intensity of parasites in goldfish (Carassius auratus L.) from Guilan } \\
\text { province fish ponds, north Iran. }\end{array}$ & Yes & $\begin{array}{l}\text { Roohi et al., } \\
2016\end{array}$ & SC \\
\hline & $\begin{array}{l}\text { Distribution and size of the barnacle Chelonibia patula fouling blue crab Callinectes } \\
\text { amnicola in southeast Nigeria }\end{array}$ & Yes & $\begin{array}{l}\text { Udoh and Otoh, } \\
2016\end{array}$ & OS \\
\hline \multirow{2}{*}{ Ichthyology } & $\begin{array}{l}\text { Some aspects of the biology of Abu mullet (Liza abu Heckel, 1843) in the Orontes River, } \\
\text { Turkey }\end{array}$ & Yes & $\begin{array}{l}\text { Ay and Özcan, } \\
2016\end{array}$ & OS \\
\hline & $\begin{array}{l}\text { Biological characteristics of European perch (Perca fluviatilis L., 1758) inhabiting Lake } \\
\text { Ladik (Samsun, Turkey) }\end{array}$ & Yes & $\begin{array}{l}\text { Saygin et al., } \\
2016\end{array}$ & OS \\
\hline $\begin{array}{l}\text { Marine } \\
\text { biology }\end{array}$ & $\begin{array}{l}\text { Fisheries and climate change: Inevitability or prophylaxis? Contributing to a necessary } \\
\text { debate }\end{array}$ & Yes & Monteiro, 2016 & PP \\
\hline \multirow{6}{*}{ Inland water } & Zooplankton structure in two interconnected ponds: similarities and differences & Yes & $\begin{array}{l}\text { Špoljar et al., } \\
2015\end{array}$ & OS \\
\hline & $\begin{array}{l}\text { Threatened fishes of the world: Coptodon walteri (Thys van den Audenaerde, 1968) } \\
\text { (Perciformes: Cichlidae) }\end{array}$ & Yes & $\begin{array}{l}\text { Konan et al., } \\
2016\end{array}$ & SC \\
\hline & $\begin{array}{l}\text { Environmental variables and ecological distribution of ichthyofauna assemblages in the } \\
\text { southeastern coastal region of the Calabar River, Nigeria }\end{array}$ & Yes & $\begin{array}{l}\text { Andem et al., } \\
2016\end{array}$ & OS \\
\hline & $\begin{array}{l}\text { Length-weight relationships of five Cultrinae fish species and two of their hybrids from } \\
\text { China }\end{array}$ & Yes & $\begin{array}{l}\text { Xiong et al., } \\
2016\end{array}$ & SC \\
\hline & $\begin{array}{l}\text { Length-weight relationships, condition index and sex ratio of mussel Lamellidens } \\
\text { corrianus (Lea, 1834) in a freshwater lake, Northwest Bangladesh }\end{array}$ & Yes & $\begin{array}{l}\text { Mondol et al., } \\
2016\end{array}$ & PC \\
\hline & $\begin{array}{l}\text { Morphometric characteristics of catfish Silurus triostegus (Heckel, 1843) from the Tigris } \\
\text { and Ahatt al-Arab rivers, Iraq }\end{array}$ & Yes & $\begin{array}{l}\text { Jawad and Al- } \\
\text { Janabi, } 2016\end{array}$ & SC \\
\hline \multirow[t]{4}{*}{ Genetics } & $\begin{array}{l}\text { The review of ecological and genetic research of Ponto-Caspian gobies (Pisces, } \\
\text { Gobiidae) in Europe }\end{array}$ & Yes & $\begin{array}{l}\text { Jakšić et al., } \\
2016\end{array}$ & RA \\
\hline & Book review: Višejezični rječnik za ribarsku struku (Multilingual dictionary of fisheries) & No & Opačak, 2016 & - \\
\hline & Book review: Biologie a ochrana mihulí (Biology and protection of lampreys) & No & Povž, 2016 & - \\
\hline & $\begin{array}{l}\text { Book review: Sladkovodne ribe in piškurji v Sloveniji (Freshwater fishes and lampreys in } \\
\text { Slovenia) }\end{array}$ & No & $\begin{array}{l}\text { Tomljanović, } \\
2016\end{array}$ & - \\
\hline \multirow[t]{3}{*}{$\begin{array}{l}\text { Supplement } \\
\text { to fishing } \\
\text { profession }\end{array}$} & Book review: Hrvatske endemske ribe (Croatian endemic fishes) & No & $\begin{array}{l}\text { Tomljanović, } \\
2016\end{array}$ & - \\
\hline & $\begin{array}{l}\text { Fish forward - sustainable seafood for the environment, people and developing } \\
\text { countries - One problem, millions affected }\end{array}$ & No & $\begin{array}{l}\text { Kanski and } \\
\text { Niedermueller, } \\
2016\end{array}$ & - \\
\hline & $\begin{array}{l}\text { Not only tourism but research and education: Aquatika - Freshwater Aquarium } \\
\text { Karlovac }\end{array}$ & No & $\begin{array}{l}\text { Jakšić and } \\
\text { Mihinjač, } 2016\end{array}$ & - \\
\hline Editorial & Editorial 2016: Changes for the Future & No & $\begin{array}{l}\text { Matulić et al., } \\
2016\end{array}$ & - \\
\hline
\end{tabular}


reviewers of Croat J Fish, including the members of Editorial Board, one of the most important goals of the Journal might be attained.

\section{NEW EDITORIAL MEMBERS}

At the last Croat J Fish Editorial Board meeting the new members were unanimously elected. After retiring Prof. Milorad Mrakovčić, his colleagues from University of Zagreb - Dr. Davor Zanella and Dr. Perica Mustafić - were elected. Additionally, Dr. Åsa Strand from the University of Gothenburg was also elected as a new member of Croat J Fish Editorial Board. We thank prof. Mrakovčic for his valuable contribution and congratulate the new members.

\section{SCOPUS CiteScore METRICS}

According to Scopus CiteScore metrics, which measure the average citations received per document published in a serial, Croat J Fish average citations received per document published in the serial for 2016 was 0.62 . SCImago Journal Rank (SJR), which measures weighted citations received by the serial for 2015, was 0.208 . Citation weighting depends on subject field and prestige of the citing serial. Source Normalized Impact per Paper (SNIP) measures actual citations received relative to citations expected for the serial's subject field. SNIP for Croat J Fish is 0.174.

\section{ISSUES IN 2016}

In 2016, 7 original scientific papers, 1 preliminary and 6 short communications, 3 review papers, 2 professional papers and 6 supplements to fishing profession were published. The manuscripts mostly continued to cover topics in freshwater aquaculture and inland waters. Other topics covered include marine biology, marine aquaculture, ichthyology, fish disease and genetics (Table 1). A total of 80 manuscript submissions were received in 2016.

\section{Sažetak}

\section{UVODNIK 2017: REFLEKSIJE I TRENUTNE SPOZNAJE}

Croatian Journal of Fisheries (Croat J Fish) nastoji i dalje održati svoje mjesto kao važan znanstveni i stručni časopis u ribarstvu. U cilju povećanja vidljivosti znanstvenih publikacija, De Gruyter Open je počeo surađivati s istraživačkom platformom Kudos. Croat J Fish je prihvaćen u BIOSIS Citation Index pod platformom Clarivate Analytics - Web of Science. Prikazana je i evaluacija časopisa u Scopus CiteScore metrics- $u$. Uvodnik također pruža informacije o člancima objavljenim u 2016. godini, kao i popis recenzenata koji su sudjelovali u postupku recenzije radova.
Ključne riječi: spoznaje, Croat J Fish, De Gruyter Open, BIOSIS Citation Index

\section{REFERENCES}

Andem, A. B., Ekanem, S. B., Oku, E. E. (2016): Environmental variables and ecological distribution of ichthyofauna assemblages in the southeastern coastal region of the Calabar River, Nigeria. Croatian Journal of Fisheries, 74, 159-171.

Ay, S., Özcan, G. (2016): Some aspects of the biology of Abu mullet (Liza abu Heckel, 1843) in the Orontes River, Turkey. Croatian Journal of Fisheries, 74, 49-55.

Edritanti, Q., Farajallah, A., Wardiatno, Y. (2016): Reproductive biology of ovigerous female Emerita emeritus (Crustacea, Decapoda) in Bengkulu coastal waters, Indonesia: egg production and reproductive output. Croatian Journal of Fisheries, 74, 103-109.

Jakšič, G, Mihinjač, T. (2016): Not only tourism but research and education: Aquatika - Freshwater Aquarium Karlovac. Croatian Journal of Fisheries, 74, 186.

Jakšić, G., Jadan, M., Piria, M. (2016): The review of ecological and genetic research of Ponto-Caspian gobies (Pisces, Gobiidae) in Europe. Croatian Journal of Fisheries, 74, 110-123.

Jawad, L. A., Al-Janabi, M. I. G. (2016): Morphometric characteristics of catfish Silurus triostegus (Heckel, 1843) from the Tigris and Ahatt al-Arab rivers, Iraq. Croatian Journal of Fisheries, 74, 179-185.

Kanski, D., Niedermueller, S. K. (2016): Fish forward sustainable seafood for the environment, people and developing countries - One problem, millions affected. Croatian Journal of Fisheries, 74, 87-88.

Khan, M.N., Shahzad, K, Chatta, A., Sohail, M., Piria, M., Treer, T. (2016): A review of introduction of common carp Cyprinus carpio in Pakistan: origin, purpose, impact and management. Croatian Journal of Fisheries, 74, 71-80.

Konan, F. K., Doffou, R. J. O., Bony, Y. K., Aliko, G. N., Assemian, G. N. (2016): Threatened fishes of the world: Coptodon walteri (Thys van den Audenaerde 1968) (Perciformes: Cichlidae). Croatian Journal of Fisheries, 74, 84-86.

Kružić, N., Mustać, B., Župan, I., Čolak, S. (2016): Meagre (Argyrosomus regius Asso, 1801) aquaculture in Croatia. Croatian Journal of Fisheries 74, 14-19.

Matulić, D., Tomljanović, T., Piria, M. (2016): Editorial 2016: Changes for the Future. Croatian Journal of Fisheries 74 , 1-5.

Mondol, M. R., Nasrin, F., Nahar, D. A. (2016): Length-weight relationships, condition index and sex ratio of mussel Lamellidens corrianus (LEA, 1834) in a freshwater lake, Northwest Bangladesh. Croatian Journal of Fisheries, 74, 172-178.

Monteiro, P. V. (2016): Fisheries and climate change: Inevitability or prophylaxis? Contributing to a necessary 
debate. Croatian Journal of Fisheries, 74, 130-140.

Okomoda, V. T., Tiamiyu, L. O., Iortim, M. (2016): The effect of water renewal on growth of Clarias gariepinus fingerlings. Croatian Journal of Fisheries, 74, 25-29.

Olaoye, O. J., Ezeri, G. N. O., Akegbejo-Samsons, Y., Awotunde, J. M., Ojebiyi, W. G. (2016): Dynamics of the adoption of improved aquaculture technologies among fish farmers in Lagos State, Nigeria. Croatian Journal of Fisheries, 74, 56-70.

Olufeagba, S. O., Okomoda, V. T. (2016): Cannibalism and performance evaluation of hybrids between Clarias batrachus and Clarias gariepinus. Croatian Journal of Fisheries, 74, 124-129.

Opačak, A. (2016): Book review: Višejezični rječnik za ribarsku struku (Multilingual dictionary of fisheries). Croatian Journal of Fisheries, 74, 38-39.

Povž, M. (2016): Book review: Biologie a ochrana mihuli (Biology and protection of lampreys), Croatian Journal of Fisheries, 74, 40-41.

Rapple, C. (2016): Hootsuite for academia? How to increase the visibility downloads and impact of publications using Kudos. available on http://blogs.lse.ac.uk/ impactofsocialsciences/2016/06/24/hootsuite-foracademia-how-to-increase-the-visibility-downloadsand-impact-of-publications-using-kudos/

Roohi, J. D., Ghasemzadeh, K., Amini, M. (2016): Occurrence and intensity of parasites in goldfish (Carassius auratus L.) from Guilan province fish ponds, north Iran. Croatian Journal of Fisheries, 74, 20-24

Saygin, S., Yilmaz, S., Yazicioglu, O., Polat, N. (2016): Biological characteristics of European perch (Perca fluviatilis L., 1758) inhabiting Lake Ladik (Samsun, Turkey). Croatian Journal of Fisheries, 74, 141-148.

Sharifinasab, Z., Banaee, M., Mohiseni, M., Noori, A. (2016): The protective role of vitamin $C$ and chitosan against paraquat-induced oxidative stress in muscles of common carp (Cyprinus carpio). Croatian Journal of Fisheries, 74, 149-158.

Solomon, S.G., Tiamiyu, L.O., Okomoda, V.T., Adaga, K. (2016): Effects of storage conditions on quality characteristics of commercial aquafeeds and growth of African catish Clarias gariepinus. Croatian Journal of Fisheries, 74, 30-37.

Špoljar, M., Tomljanović, T., Dražina, T., Lajtner, J., Štulec, H., Matulić, D. (2016): Zooplankton structure in two interconnected ponds: similarities and differences. Croatian Journal of Fisheries 74, 6-13.

Tomljanović, T. (2016): Book review: Hrvatske endemske ribe (Croatian endemic fishes). Croatian Journal of Fisheries, 74, 43-44.
Tomljanović, T. (2016): Book review: Sladkovodne ribe in piškurji v Sloveniji (Freshwater fishes and lampreys in Slovenia). Croatian Journal of Fisheries, 74, 42.

Udoh, J. P., Otoh, A. J. (2016): Distribution and size of the barnacle Chelonibia patula fouling the blue crab Callinectes amnicola in southeast Nigeria. Croatian Journal of Fisheries, 74, 93-102.

Xiong, X., Zhao, B., Nie, C., Wang, W., Gao, Z. (2016): Lengthweight relationships of five Cultrinae fish species and two of their hybrids from China. Croatian Journal of Fisheries, 74, 81-83.

Appendix 1. List of reviewers for the Croatian Journal of Fisheries between 1 January 2016 and 31 December 2016

Pablo Almazan-Rueda

Paul Annune

Jakša Bolotin

Ružica Brečićc

Ivana Buj

Asli Cadun

Martin Čech

Slavica Čolak

Vesna Djikanovič

Branko Dragičević

Josipa Ferri

Jörg Freyhof

Jian Gao

Ana Gavrilović

Emil Gjurčevič

Dragojla Golub

Matt Griffin

Lari Hadelan

Predrag Ivanković

Ivan Jakovlić

Dinko Jelkič

Jurica Jug-Dujaković

Pavel Jurajda

Muhammad Naeem Khan

Zrinka Knezović

Radoslaw Kowalski

David Kuhn

Jawad A. Laith

Emmanuel O. Lawson

Istvan Lehoczky

Ružica Lončarič

Zoran Marčić

Sanja Matič Skoko

Daniel Matulić
Ewan Mclean
Bosiljka Musać
Jayshree Nellore
Viktor Tosin Okomoda
Dušan Palić
Jiri Patoka
Alexey Pimakhin
Selma Pintarić
Marina Piria
Metka Povž
Marie Prchalova
Rajeev Raghavan
Ana Razum
Raquel Salazar-Lugo
Guillaume Salze
Vladica Simić
Predrag Simonović
Gorenka Sinovčić
Ali Serhan Tarkan
Orhideja Tasevska
Silvia Tejada
Ivančica Ternjej
Xiang Gao Tian
Emilio Tibaldi
Tea Tomljanovič
Natalija Topič Popović
Tomislav Treer
Erhan Ünlü
Damir Valič
Sanja Vidaček
Savas Yilmaz

Daniel Matulić

Bosiljka Musać

Jayshree Nellore

Viktor Tosin Okomoda

Jiri Patoka

Alexey Pimakhin

Selma Pintaric

Marina Piria

Metka Povž

Marie Prchalova

Rajeev Raghavan

Ana Razum

Raquel Salazar-Lugo

Salze

Predrag Simonović

Gorenka Sinovčić

Ali Serhan Tarkan

Orhideja Tasevska

Silvia Tejada

Ivančica Ternjej

Xiang Gao Tian

Emilio Tibaldi

Tea Tomljanović

Natalija Topić Popović

Tomislav Treer

an Ünlü

Sanja Vidaček

Savas Yilmaz 